\title{
Alterações bromatológicas nas silagens de milho submetidas a crescentes tempos de exposição ao ar após "desensilagem”
}

\author{
Changes in chemical composition of maize silages after increasing periods of air exposure at "feed-out"
}

\author{
João Pedro Velho ${ }^{1 *}$ Paulo Roberto Frenzel Mühlbach ${ }^{1}$ Teresa Cristina Moraes Genro ${ }^{2}$ \\ Luis Maria Bonnecarrère Sanchez ${ }^{3}$ José Laerte Nörnberg ${ }^{3}$ Mariane Garcia Orqis ${ }^{2}$ \\ Jaline Rodrigues Falkenberg ${ }^{3}$
}

\section{RESUMO}

O experimento foi conduzido em delineamento completamente casualizado, com o objetivo de avaliar os efeitos da exposição de uma silagem ao ar por zero, 12, 24 e 36 horas após a "desensilagem". A ensilagem de um cultivo de milho "safrinha” foi realizada no dia 18/05/2004 em mini-silos com capacidade de 30 litros, com quatro repetições por tratamento, quando os grãos de milho se encontravam no estádio $1 / 2$ leitoso $1 / 2$ farináceo. Os diferentes tempos de exposição ao ar após a “desensilagem" afetaram significativamente $(P<0,05)$ o teor de fibra em detergente neutro, corrigido para cinzas e proteínas, e o teor de lignina em ácido sulfúrico. Não houve efeito nos carboidratos não estruturais e nas frações nitrogenadas. Conclui-se que um período de 12 horas de aerobiose, após a "desensilagem", afeta o valor nutritivo das silagens de milho.

Palavras-chave: açúcares, amido, fibra em detergente neutro, lignina, proteínas.

\section{ABSTRACT}

The experiment in a completely randomized design aimed at testing the effect of air exposure of maize silages at "feed-out" on chemical composition. Silages were prepared on May $18^{\text {th }}$, 2004 from a late season harvest of a crop at the half milky half dough kernel stage and chopped materials were packed in 30 liters mini-silos. Four treatments with four replicates consisted of air exposure of silages removed from the mini-silos after periods of zero, 12 hours, 24 hours or 36 hours until sampling for chemical analysis. Air exposure affected significantly $(P<0.05)$ neutral detergent fiber values (corrected for ashes and protein) and lignin contents, without effects on non-structural carbohydrates and nitrogenous fractions. It is concluded that a 12 hour air exposure period after "feed-out" can affect the nutritive value of maize silage.

Key words: sugar, starch, neutral detergent fibre, lignin, protein.

\section{INTRODUÇÃO}

$\mathrm{O}$ processo de ensilagem não melhora a qualidade do alimento, mas visa, manter a qualidade do material original (VAN SOEST, 1994). Assim, é de extrema importância que este processo seja realizado de forma correta, minimizando as perdas energéticas inevitáveis (calor e $\mathrm{CO}_{2}$ ) do sistema, durante a fermentação dos carboidratos solúveis em ácido láctico. Por conseguinte, o procedimento de retirada da silagem do silo, que vem sendo denominado de "desensilagem", deve evitar perdas indesejáveis que possam comprometer a relação benefício/custo, como a oxidação dos açúcares solúveis e a degradação do ácido láctico produzido na fermentação, aumentando a proporção de parede celular, com redução do seu valor nutritivo.

Apesar da crescente difusão da silagem de milho como alimento volumoso, verifica-se a utilização de conceitos equivocados na escolha de híbridos, nos manejos culturais e no processo de ensilagem, onde a qualidade do produto final não é priorizada (DIAS, 2002). Acrescentem-se a esses os conceitos equivocados de "desensilagem", como acontece com a retirada irregular da espessura da fatia de silagem e com o tempo excessivo entre a retirada e o fornecimento aos animais.

Os procedimentos de "desensilagem" podem afetar a qualidade nutritiva do produto até seu consumo. A silagem sem a presença de oxigênio e com

${ }^{1}$ Universidade Federal do Rio Grande do Sul (UFRGS), Porto Alegre, RS, Brasil. E-mail: velhojp@yahoo.com.br. *Autor para correspondência.

${ }^{2}$ Empresa Brasileira de Pesquisa Agropecuária (EMBRAPA) Pecuária Sul, Bagé, RS, Brasil.

${ }^{3}$ Universidade Federal de Santa Maria (UFSM), Santa Maria, RS, Brasil. 
acúmulo de ácido láctico resulta na diminuição do $\mathrm{pH}$, na inibição do metabolismo microbiano e na preservação dos nutrientes. Entretanto, quando exposta ao ar, certos microrganismos oportunistas se tornam metabolicamente ativos, produzem calor e consomem nutrientes da silagem (RANJIT \& KUNG Jr., 2000). A degradação aeróbia da silagem pode ser causada por fungos e bactérias acetogênicas que utilizam açúcares residuais e produtos da fermentação, como o ácido láctico, como substratos, elevando a temperatura em até $45^{\circ} \mathrm{C}$ (ROTZ \& MUCK, 1994).

A "desensilagem" de camadas inferiores a $15 \mathrm{~cm}$ ocasiona perdas de $11 \%$ de matéria seca, após a abertura do silo (CLARK, 2005). O tempo necessário para o surgimento do aquecimento da fatia de corte do silo depende de fatores como: concentração de microrganismos aeróbios, tempo de exposição, características das silagens e da temperatura ambiente (MUCK \& BOLSEN, 1991), além da densidade de compactação. O procedimento de "desensilagem" pode evitar que a silagem exposta ao ar aqueça e resulte na degradação dos produtos da fermentação e na perda excessiva de matéria seca. É recomendada a remoção diária de uma fatia de 15 a $30 \mathrm{~cm}$ de espessura. Contudo, em condições climáticas quentes e úmidas pode ser necessário retirar uma fatia de espessura de $45 \mathrm{~cm}$ ou mais, a fim de prevenir essas perdas decorrentes da aerobiose. Isto ocorre em silagens de alta umidade como as de planta inteira de milho, de sorgo, de cereais de inverno e de grão úmido de milho (BOLSEN, 2005). Silos mais estreitos, que permitam a intensa compactação com tratores e com um consumo diário de silagem que propicie o corte de fatias mais espessas, favorecem o correto manejo de retirada de silagem (WOOLFORD, 1990).

Foi também constatado que a produção de leite de vacas alimentadas com silagens deterioradas pela exposição ao ar diminuiu $3,2 \mathrm{~kg}$ por dia em relação àquelas alimentadas com forragens frescas ou silagem de milho aerobiamente estável (HOFFMAN \& OCKER, 1997). A presença de ar durante a "desensilagem" pode resultar em perdas maiores de matéria seca do que no silo fechado (WOOLFORD, 1990). As perdas de matéria seca decorrentes da infiltração de ar durante o enchimento do silo variam de 1 a $2 \%$, enquanto que as decorrentes da aeração na "desensilagem" variam de 2 a $19 \%$. Já as perdas totais não perceptíveis podem variar de 10 a 25\% (MCGECHAN, 1990).

Em muitas propriedades, a silagem é frequentemente submetida a diversas magnitudes de deterioração aeróbia, antes e durante seu fornecimento aos animais, pela incapacidade de se remover apenas a quantidade necessária para alimentação, resultando em prolongada exposição ao ar da silagem excedente retirada. Outra forma comum de deterioração da silagem, por exposição ao ar é o mau fechamento do silo entre as retiradas. Alguns produtores americanos, com o intuito de diminuírem o trabalho de retirada da silagem, ou quando compram a silagem que é transportada em caminhões, optam por alimentar os animais uma vez a cada dois ou três dias. Desta forma, a silagem fica exposta ao ar por vários dias, perdendo seu valor nutricional e causando riscos ambientais pelo descarte da porção deteriorada (RANJTT \& KUNG Jr., 2000).

Neste estudo, foram analisados os efeitos do tempo de exposição ao ar, após a "desensilagem" de silagens de milho "safrinha" de planta inteira, sobre o valor nutritivo, simulando-se períodos de demora entre a retirada da silagem e o seu fornecimento aos animais.

\section{MATERIAL E MÉTODOS}

O trabalho de campo foi desenvolvido na Granja Três Capões, no município de Palmeira das Missões, RS. O tipo de solo é classificado como latossolo vermelho distrófico típico LVd3 (STRECK et al., 2002). O clima é do tipo Cfa, subtropical com verões quentes e chuvas bem distribuídas ao longo do ano, com temperatura média de $22^{\circ} \mathrm{C}$ no período mais quente (MORENO, 1961).

O híbrido AG5011 foi semeado com espaçamento entre linhas de $0,75 \mathrm{~m}$ e o estande final de plantas atingiu 50.000 por hectare. A adubação NPK de base foi de $250 \mathrm{~kg} \mathrm{ha}^{-1}$ e a adubação de cobertura nitrogenada com uréia foi de $100 \mathrm{~kg} \mathrm{ha}^{-1}$, dividida em duas aplicações. A colheita foi feita com os grãos no estádio $1 / 2$ leitoso e $1 / 2$ farináceo, no dia 18 de maio de 2004, e ocorreu entre 16 e 18 horas, realizada manualmente, com o corte a 15 centímetros acima do nível do solo. No momento do corte teve-se o cuidado de não incluir as bordaduras da lavoura, seguindo-se com o corte das demais plantas até a obtenção de, aproximadamente, $1.000 \mathrm{~kg}$ de matéria verde. A seguir, procedeu-se à picagem das plantas em ensiladeira regulada para um tamanho de corte teórico médio de $1,2 \mathrm{~cm}$.

Antes da ensilagem, foram coletadas amostras (1,0kg) das plantas verdes (material original), as quais foram acondicionadas em sacos plásticos e congeladas a $-18^{\circ} \mathrm{C}$. Na tabela 1 , é apresentada a caracterização do material verde retirado no momento da picagem. A ensilagem foi realizada em mini-silos, com quatro repetições por tratamento, constituídos por baldes plásticos com capacidade de 30 litros, sendo a compactação realizada através de pisoteio. No 
Tabela 1 - Teores médios de matéria seca (MS), matéria orgânica (MO), pH e extrato etéreo (EE), carboidratos estruturais e constituintes glicídicos, constituintes nitrogenados e estimativas dos nutrientes digestíveis totais do material original e das silagens após a "desensilagem".

\begin{tabular}{|c|c|c|c|c|c|c|c|}
\hline \multirow{2}{*}{ Variável } & \multirow{2}{*}{ Material Original* } & \multicolumn{4}{|c|}{ Intervalo entre retirada e utilização das silagens (Horas) } & \multirow{2}{*}{$\mathrm{F}$} & \multirow{2}{*}{ Prob. $>$} \\
\hline & & Zero & 12 & 24 & 36 & & \\
\hline MS (\%) & 30,83 & 28,71 & 27,91 & 28,41 & 28,81 & 3,531 & 0,062 \\
\hline $\mathrm{MO}(\% \mathrm{MS})$ & 97,46 & 95,97 & 96,48 & 96,71 & 96,74 & 2,479 & 0,127 \\
\hline $\mathrm{pH}$ & 5,62 & 3,72 & 3,73 & 3,73 & 3,76 & 0,875 & 0,489 \\
\hline $\mathrm{EE}(\% \mathrm{MS})$ & 2,20 & $2,28 \mathrm{a}$ & $2,16 \mathrm{a}$ & $2,35 \mathrm{a}$ & $2,80 \mathrm{~b}$ & 12,524 & 0,001 \\
\hline \multicolumn{8}{|c|}{ Carboidratos estruturais e constituintes glicídicos } \\
\hline FDN (\%MS) & 51,95 & $51,47 \mathrm{a}$ & $53,33 b$ & $51,24 \mathrm{a}$ & $52,32 \mathrm{ab}$ & 5,397 & 0,021 \\
\hline FDNcp (\%MS) & 49,45 & $49,22 \mathrm{a}$ & $51,03 b$ & $49,39 a$ & $50,60 \mathrm{ab}$ & 6,490 & 0,012 \\
\hline FDA (\%MS) & 26,06 & 27,52 & 28,50 & 28,38 & 28,55 & 2,567 & 0,119 \\
\hline Lignina (\%MS) & 2,44 & $2,57 \mathrm{a}$ & $2,61 \mathrm{a}$ & $2,72 \mathrm{a}$ & $2,91 b$ & 9,825 & 0,003 \\
\hline Hem. (\%MS) & 25,89 & $23,95 \mathrm{a}$ & $24,83 a$ & $22,86 b$ & $23,76 \mathrm{ab}$ & 8,612 & 0,005 \\
\hline Cel. (\%MS) & 23,62 & 24,98 & 25,88 & 30,06 & 25,63 & 1,164 & 0,376 \\
\hline AS (\%MS) & 9,37 & 2,15 & 2,27 & 2,68 & 2,76 & 2,416 & 0,134 \\
\hline Amido (\%MS) & 11,70 & 12,48 & 11,83 & 15,84 & 12,48 & 1,881 & 0,203 \\
\hline MORIE (\%MS) & 73,94 & $71,53 \mathrm{a}$ & $74,77 \mathrm{~b}$ & $74,58 b$ & $75,42 b$ & 15,025 & 0,001 \\
\hline CHOT (\%MS) & 87,74 & 85,69 & 86,99 & 86,16 & 85,92 & 2,850 & 0,097 \\
\hline CNE (\%CHOT) & 43,01 & $41,70 \mathrm{ab}$ & $40,53 b$ & $42,35 \mathrm{a}$ & $40,68 b$ & 1,724 & 0,012 \\
\hline \multicolumn{8}{|c|}{ Fracionamento dos carboidratos segundo Sniffen et al. (1992) } \\
\hline Fração A (\%CHOT) & 31,31 & 29,22 & 28,69 & 26,51 & 28,20 & 1,307 & 0,486 \\
\hline Fração $\mathrm{B}_{1}(\% \mathrm{CHOT})$ & 11,70 & 12,48 & 11,84 & 15,84 & 12,48 & 2,353 & 0,203 \\
\hline Fração $\mathrm{B}_{2}(\% \mathrm{CHOT})$ & 50,35 & $51,21 \mathrm{ab}$ & $52,29 \mathrm{~b}$ & $50,22 \mathrm{a}$ & $51,21 \mathrm{ab}$ & 5,504 & 0,020 \\
\hline Fração C (\%CHOT) & 6,74 & $7,09 \mathrm{a}$ & $7,18 \mathrm{a}$ & $7,43 \mathrm{ab}$ & $8,10 \mathrm{~b}$ & 8,567 & 0,005 \\
\hline \multicolumn{8}{|c|}{ Constituintes nitrogenados } \\
\hline $\mathrm{PB}(\% \mathrm{MS})$ & 7,52 & 8,00 & 7,33 & 8,19 & 8,02 & 3,625 & 0,058 \\
\hline $\mathrm{N}-\mathrm{NH}_{3}(\% \mathrm{~PB})$ & 2,28 & $3,87 \mathrm{ab}$ & $4,20 \mathrm{~b}$ & $3,76 \mathrm{a}$ & $3,96 \mathrm{ab}$ & 7,243 & 0,020 \\
\hline NIDN (\%PB) & 24,48 & 17,02 & 19,90 & 18,29 & 15,76 & 0,261 & 0,851 \\
\hline NIDA $(\% \mathrm{~PB})$ & 9,10 & 13,49 & 6,81 & 5,74 & 9,35 & 3,143 & 0,080 \\
\hline \multicolumn{8}{|c|}{ Estimativa dos nutrientes digestíveis totais } \\
\hline Weiss $(\%)$ & 71,22 & 69,57 & 69,72 & 70,14 & 70,09 & 0,827 & 0,512 \\
\hline NRC (\%) & 68,95 & 67,41 & 67,54 & 67,98 & 67,98 & 1,063 & 0,412 \\
\hline
\end{tabular}

* Os dados do material original não fazem parte da análise estatística. FDN = fibra em detergente neutro; FDNcp = fibra em detergente neutro corrigida para cinzas e proteína; FDA= fibra em detergente ácido; Hem. = hemicelulose; Cel = celulose; AS = açúcares solúveis; MORIE $=$ matéria orgânica do resíduo insolúvel em etanol a 80\%; CHOT $=$ carboidratos totais; $\mathrm{CNE}=$ carboidratos não estruturais; $\mathrm{PB}=$ proteína bruta; $\mathrm{N}-\mathrm{NH}_{3}=$ nitrogênio amoniacal; $\mathrm{NIDN}=$ nitrogênio insolúvel em detergente neutro; NIDA = nitrogênio insolúvel em detergente ácido.

momento da abertura dos mini-silos, realizada 45 dias após o fechamento, as camadas superiores, inferiores e laterais de cada mini-silo foram desprezadas. Os tratamentos de "desensilagem" consistiram na retirada da silagem de cada mini-silo, em quatro repetições, permanecendo o material amontoado em cima de uma lona plástica, exposto ao ambiente numa sala fechada com piso de madeira. Após 12, 24 e 36 horas de exposição ao ar, as amostras foram retiradas. A temperatura da silagem exposta foi monitorada utilizando-se termômetros de mercúrio que eram inseridos no monte meia hora antes da retirada das amostras, numa profundidade de 10 centímetros. As temperaturas médias dos dias 2 e 3 de julho de 2004 foram de $23,8 \mathrm{e} 20,5^{\circ} \mathrm{C}$, respectivamente, conforme o $8^{\circ}$ DISME.

Imediatamente após a obtenção das amostras, procedeu-se à determinação do teor de matéria parcialmente seca, com o material por 72 horas em estufa de circulação e renovação de ar forçada a $55 \pm 0,1^{\circ} \mathrm{C}$ em parte do material até peso constante, sendo o restante armazenado a $-18^{\circ} \mathrm{C}$.

Para as determinações de $\mathrm{pH}$ e nitrogênio amoniacal, prensou-se uma quantidade de silagem 
suficiente para coleta de $50 \mathrm{~mL}$ de extrato. $\mathrm{O}$ pH foi determinado no extrato utilizando-se potenciômetro digital e o teor de nitrogênio amoniacal foi determinado por método colorimétrico (WEATHERBURN, 1967).

As determinações de matéria seca (MS), matéria orgânica (MO), extrato etéreo (EE), fibra em detergente ácido (FDA), lignina em detergente ácido (ácido sulfúrico), proteína bruta $(\mathrm{PB})$, nitrogênio insolúvel em detergente neutro (NIDN) e nitrogênio insolúvel em detergente ácido (NIDA) foram realizadas segundo procedimentos descritos por SILVA \& QUEIROZ (2002), utilizando amostras moídas em moinho do tipo Willey com peneira de $1 \mathrm{ml}$. Ressalte-se que a determinação da fibra em detergente neutro (FDN) não utilizou sulfito de sódio na solução em detergente neutro, sendo empregada a-amilase. Por isso, a proteína remanescente na FDN foi subtraída após a multiplicação do fator 6,25 pelo teor do NIDN. A abreviação FDNcp expressa o teor de fibra em detergente neutro determinada com o uso de a-amilase termoestável, descontando-se a proteína insolúvel em detergente neutro (PIDN) e as cinzas residuais.

As determinações de açúcares solúveis (AS) e de matéria orgânica do resíduo insolúvel em etanol a $80 \%$ (MORIE) foram realizadas conforme HALL (2000). A determinação de amido seguiu a metodologia descrita por WALTER (2005). Após a realização das determinações bromatológicas, foram efetuados os cálculos do fracionamento dos carboidratos segundo SNIFFEN et al. (1992).

Os valores de nutrientes digestíveis totais (NDT) foram estimados segundo WEISS et al. (1992) e NRC (2001), respectivamente, com as equações:

$$
\mathrm{NDT}_{1 \mathrm{x}}(\mathrm{g} / \mathrm{kg} \mathrm{de} \mathrm{MS})=\mathrm{CNFvd}+\mathrm{PBvd}+(\text { EE- }
$$
10) $\times 2,25+$ FDNvd -70

FDNvd - 7

$$
\mathrm{NDT}_{1 \mathrm{x}}(\%)=\mathrm{CNFvd}+\mathrm{PBvd}+(\mathrm{EE}-1) \times 2,25+
$$

em que: NDT1 $\mathrm{x}=$ nutrientes digestíveis totais para o consumo de $1 \mathrm{x}$ a manutenção; CNFvd = carboidratos não fibrosos verdadeiramente digestíveis; PBvd = proteína bruta verdadeiramente digestível; FDNvd = fibra em detergente neutro verdadeiramente digestível e os valores 70 ou 7 referem-se à constante de desconto de constituintes metabólicos fecais.

O experimento foi conduzido através de delineamento completamente casualizado, com quatro repetições por tratamento, onde as unidades experimentais foram os mini-silos. As análises estatísticas foram realizadas seguindo o modelo estatístico: $\mathrm{y}_{\mathrm{ij}}=\mu+\alpha \mathrm{i}+\beta \mathrm{j}+\varepsilon_{\mathrm{ij}}$, onde: $\mathrm{y}_{\mathrm{ij}}=$ variável resposta; $\mu=$ média geral; $\alpha=$ efeito da simulação dos tempos entre retirada da silagem e sua utilização; $i=$ Zero, doze, 24 e 36 horas; $\beta \mathrm{j}$ = parâmetro associado com as unidades experimentais; $j=$ Mini-silo A, B, C e $\mathrm{D} ; \varepsilon_{\mathrm{ij}}=$ erro aleatório. Foi realizada análise de variância para medidas repetidas no tempo sobre os parâmetros analisados nas silagens expostas ao ar após a "desensilagem" empregando-se o software SPSS (1999). Para as variáveis que diferiram estatisticamente, a comparação entre as médias foi por meio da diferença mínima significativa, em nível de 5\%. O material original não foi incluído na análise estatística.

\section{RESULTADOS E DISCUSSÃO}

Os teores de matéria seca e orgânica e os valores de $\mathrm{pH}$ apresentados na tabela 1 não sofreram efeitos dos tempos de exposição ao ar, após a “desensilagem". Entretanto, RANJTT \& KUNG Jr. (2000) obtiveram $\mathrm{pH}$ de 5,44 para plantas de milho colhidas com $31,3 \%$ de MS e a silagem deste material após 100 dias apresentou $\mathrm{pH}$ de 3,66. No entanto, quando esta silagem foi exposta ao ar por 12, 24, 36, 48 e 72 horas, em sala fechada com temperatura constante de $22^{\circ} \mathrm{C}$, o pH aumentou $(\mathrm{P}<0,05)$ para 3,85, 3,81, 3,77, 4,55 e 5,02, respectivamente. FILYA (2003), expondo silagem de milho ao ar por cinco dias, verificou elevação do $\mathrm{pH}$ de 3,72 para 6,18 , e desenvolvimento de leveduras e fungos com elevação das contagens de 3,86 para 7,26 e de 3,26 para 3,45 $\log 10$ de unidades formadoras de colônia por grama de silagem, respectivamente. Os teores de FDA, celulose, açúcares solúveis, amido, carboidratos totais e frações $A$ e $B_{1}$ dos carboidratos também não sofreram efeitos dos tempos de exposição ao ar, após a “desensilagem". Os teores de FDN e FDNcp, lignina, hemicelulose, matéria orgânica do resíduo insolúvel em etanol a $80 \%$, e as frações $\mathrm{B}_{2}$ e $\mathrm{C}$ dos carboidratos foram afetados $(\mathrm{P}<0,05)$.

Na tabela 1, é apresentada a caracterização dos carboidratos estruturais do material original, o qual, pelo teor de FDNcp, pode ser considerado como de qualidade média, em comparação com os valores reportados na literatura européia (38,5\%) MULLIGAN et al. (2002) e norte-americana (41,3\%) QIU et al. (2003). No entanto, quando esse valor $(49,45 \%)$ é comparado com os descritos por VALADARES FILHO et al. (2002), com teor médio de FDN na MS de 163 amostras de silagem de milho de $55,68 \%$, pode-se dizer que o milho "safrinha" do presente experimento apresenta valor aceitável, mesmo descontadas as cinzas e a proteína eventualmente contidas nos valores de FDN descritos por aqueles autores. O teor de FDNcp (Tabela 1) do material original é inferior ao valor apresentado por TEDESCHI et al. (2002) de 53,2\% de FDN, para silagem de milho brasileira. 
As diferenças numéricas entre os teores de FDN e FDNcp são oriundas da subtração das cinzas e PIDN na FDNcp, cujas amplitudes indicam a importância destas correções para classificação das silagens quanto à qualidade. Porém, na maior parte da bibliografia nacional sobre silagem de milho, os autores não indicam, na maioria das vezes, a forma em que foi expresso o teor de FDN. Isto dificulta ao leitor avaliar se a silagem é de boa ou de média qualidade, já que esta variação pode chegar a cinco ou seis unidades percentuais. Em função deste tipo de variações em nível mundial, MERTENS (2002 e 2003) realizou trabalho avaliando diferentes protocolos de determinação da fibra dietética insolúvel e propôs normas para os procedimentos analíticos e para a apresentação dos resultados, sugerindo que as abreviaturas empregadas informem a metodologia utilizada.

As diferenças entre FDN e FDNcp têm maior amplitude quanto menor a qualidade nutricional do alimento, em decorrência de menor teor de matéria orgânica. HERNÁNDEZ et al. (2002) observaram diferenças de 2,22 e 1,39 unidades percentuais entre FDN e FDNcp, respectivamente, para silagem de milho sem ou com adição de inoculante bacteriano.

Comparando os teores de FDN de silagens de milho da literatura nacional com dados da literatura americana e européia, MÜHLBACH (2003) verificou diferenças da ordem de 15 e 25 unidades percentuais a mais para silagem de milho produzida no Brasil. Para o autor, isto sugere a necessidade de ajustes no modo de expressar o teor de FDN e nos procedimentos de produção das silagens de milho, especialmente quando estas forem elaboradas para dietas de ruminantes de alta produção, o que requer baixo teor de FDN. Todavia, segundo NOGUERA (2002), somente as análises químicas dos alimentos não explicam todos os aspectos da digestão nos ruminantes, pois além das informações sobre os teores de celulose, hemiceluloses, pectina e lignina nas forrageiras, necessário seria conhecer a distribuição destes constituintes na parede celular. Portanto, para se obter o valor energético de um alimento com precisão e exatidão, torna-se imprescindível a determinação da hemicelulose e também o conhecimento de suas relações com os demais componentes do alimento. As forrageiras e os cereais são constituídos por 50 a $80 \%$ de carboidratos (VAN SOEST, 1994). Este mesmo autor afirma que as características nutritivas dos carboidratos dependem dos seus componentes solúveis, das suas ligações com polifenóis, bem como de outros fatores físico-químicos.

$\mathrm{O}$ efeito significativo $(\mathrm{P}<0,05)$ para os crescentes tempos de exposição ao ar após a "desensilagem" sobre o teor de FDNcp (Tabela 1), que aumentou em 1,81 unidade percentual já nas primeiras 12 horas de exposição ao ar, sugere que, na prática, a retirada de silagem do silo deve ocorrer momentos antes do seu fornecimento aos animais. OLIVEIRA (2001) recomenda que, se a dieta for fracionada em duas ou três refeições ao dia, a silagem também deverá ser retirada duas ou três vezes antes da mistura da dieta e fornecimento aos animais, evitando assim perdas indesejáveis no seu valor nutricional.

O teor de lignina (Tabela 1 ) apresentou efeito significativo $(\mathrm{P}<0,05)$, aumentando com os crescentes tempos de exposição ao ar após a "desensilagem”. Apesar deste incremento, os valores ficaram abaixo daqueles observados para silagem de milho por CABRAL et al. (2000), de 4,37\% da MS, por CAMPOS et al. (2001), de 3,6\% da MS para silagem, com 29,6\% de MS, e por HERNÁNDEZ et al. (2002), de 5,35 e 5,29\% da MS, respectivamente para silagem sem e com inoculante.

Os teores de AS (Tabela 1) não foram afetados pelo tempo de exposição ao ar após a "desensilagem". Entretanto, constatou-se efeito significativo $(\mathrm{P}<0,05)$ nos teores de matéria orgânica do resíduo insolúvel em etanol a 80\% (MORIE). A determinação da MORIE é uma técnica de baixo custo e de fácil realização e, segundo HALL et al. (1997), soluções de etanol aquoso têm sido usadas para extrair açúcares simples, oligossacarídeos e outras substâncias de baixo peso molecular de amostras de alimentos preparadas para análise de carboidratos. Portanto, o aumento dessa fração pela exposição aeróbia da silagem indica uma degradação de glicídios que posteriormente, no rúmen, farão falta na síntese de proteína microbiana. RANJIT \& KUNG Jr. (2000), submetendo silagem de milho à exposição ao ar por 12 , $24,36,48$ e 72 horas, verificaram que os carboidratos solúveis em água diminuíram $(\mathrm{P}<0,05)$ de $3,68 \%$ da $\mathrm{MS}$ para $3,40,2,12,1,66,1,46$, e $1,35 \%$ da $\mathrm{MS}$, respectivamente, conforme os tempos de exposição anteriormente citados.

A degradação aeróbia da silagem pode ser causada por fungos e bactérias acetogênicas, que utilizam açúcares residuais e produtos da fermentação como substratos, elevando a temperatura das silagens até $45^{\circ} \mathrm{C}$ (ROTZ \& MUCK, 1994). No presente trabalho, o efeito negativo da aerobiose não foi intenso devido, possivelmente, ao fato de que a temperatura da silagem, nas condições do experimento, permaneceu em $20^{\circ} \mathrm{C}$ durante as 36 horas de exposição ao ar após a “desensilagem", o que, na prática, poderia ser diferente. A deterioração aeróbia da silagem nem sempre é acompanhada pelo aquecimento da massa, especialmente quando o teor de MS é baixo devido à 
absorção pela água do calor gerado. Contudo, a deterioração aeróbia é invariavelmente acompanhada por perdas dos ácidos orgânicos, de proteínas e de carboidratos (WOOLFORD, 1990).

Utilizando silagens de milho com $28 \%$ de MS e com densidade de compactação de $625 \mathrm{~kg}$ de matéria verde por metro cúbico, SENGER et al. (2004a) determinaram um teor de açúcares solúveis residual na silagem de apenas $1 \%$ na MS, inferior aos resultados obtidos no presente trabalho, diferindo provavelmente pelo fato dos estádios de maturação dos grãos serem diferentes. RODRIGUES et al. (2004), trabalhando com silagens de milho de 35,26 e 44,06\% de MS, obtiveram, respectivamente, 27,04 e $24,46 \%$ de amido na MS. No presente estudo, o teor de amido variou de $11,83 \%$ a $15,84 \%$ da MS, conseqüência do cultivo extemporâneo do milho "safrinha" e do ponto de colheita.

Os valores de carboidratos totais (Tabela 1) são semelhantes aos obtidos por BACKES et al. (2000) para silagens de milho de planta inteira sem $(87,25 \%) \mathrm{e}$ com inoculante $(89,11 \%)$. Porém, o fracionamento dos carboidratos, segundo SNIFFEN et al. (1992), apresentou valores diferentes daqueles reportados por BACKES et al. (2000), que obtiveram 15,42 e 15,83\%; 12,67 e $11,28 \% ; 49,60$ e $53,88 \% ; 9,56$ e $8,12 \%$, respectivamente, para as frações $\mathrm{A}, \mathrm{B}_{1}, \mathrm{~B}_{2}$ e $\mathrm{C}$, para as silagens sem e com inoculante, o que pode ser explicado pelos pontos de colheita que também foram diferentes. Diferenças na constituição dos carboidratos em um mesmo alimento devem ser ponderadas pelo nutricionista, uma vez que podem gerar diferentes resultados. Segundo SNIFFEN et al. (1992), os carboidratos podem ser classificados de acordo com as taxas de degradação sendo: Fração A (açúcares solúveis) de rápida degradação, Fração $\mathrm{B}_{1}$ (amido) de média degradação, Fração $\mathrm{B}_{2}$ (parede celular disponível) de lenta degradação e Fração $C$ (parede celular indigestível) indegradável. Comparando os dados da tabela 1 com os valores obtidos por MELLO \& NÖRNBERG (2004), que avaliaram híbridos de milho na Depressão Central do Rio Grande do Sul, as quantidades de carboidratos totais (CHOT) de 85,9\% na MS foram semelhantes, enquanto que a fração carboidratos não estruturais (CNE) foi levemente maior naquele estudo $(42,47 \%$ dos CHOT).

Se as silagens de milho do presente trabalho fossem fornecidas como alimento único a animais em manutenção, não necessitariam, ao menos teoricamente, de correções para os teores de PB, que estão acima do valor mínimo de $7 \%$, aceito como limitante do crescimento microbiano para potencializar a fermentação ruminal.
Silagens que tiveram fermentação adequada apresentam pH de 3,8 a 4,2, teor de ácido lático de 6,0 a $8,0 \%$ da MS, ácido acético menor que 2,0\% da MS, ácido propiônico de 0 a 1,0\% da MS, ácido butírico menor que $0,1 \%$ da $\mathrm{MS}$ e $\mathrm{N}-\mathrm{NH}_{3}$ menos que $10 \%$ do nitrogênio total (FERREIRA, 2001). Os teores de N$\mathrm{NH}_{3}$ em relação a $\mathrm{PB}$ (Tabela 1) são considerados baixos, indicando que, sob este aspecto, a fermentação foi adequada, sendo esses valores menores que os obtidos por SENGER et al. (2004b) para silagens bem compactadas com $28 \%$ de MS $(5,27 \%$ da PB). Os teores de NIDA do material original bem como da silagem são altos, mas encontram-se dentro da amplitude de variação que VAN SOEST (1994) sugere como normal (3 a 15\% da MS).

As diferenças numéricas apresentadas na tabela 1 para NDT1x entre os valores obtidos pelas fórmulas de WEISS et al. (1992) e NRC (2001) são decorrentes de duas diferenças nas equações: a primeira é que WEISS et al. (1992) consideram que a proteína insolúvel em detergente ácido apresenta digestibilidade de $30 \%$, a qual é adicionada ao cálculo da FDNvd; e a segunda é que o NRC (2001) propõe um fator de ajuste para processamento (FAP) para a fração carboidratos não fibrosos. Para o cálculo do NDT1x (Tabela 1), utilizou-se o FAP 0,94, proposto para silagem de milho "normal".

Os teores de NDT1x (Tabela 1), calculados pela fórmula de WEISS et al. (1992), são superiores, e os calculados pela fórmula do NRC (2001) são semelhantes ao valor descrito pelo NRC (2001) para silagem de milho "normal" $(68,8 \%)$ com MS entre $32 \mathrm{e}$ $38 \%$. Silagens de milho contêm concentrações apreciáveis de amido e FDN e variações nas suas digestibilidades podem afetar o valor energético (WEISS, 2005). Porém, como no presente experimento, não ocorreu variação no teor de amido e pequena $(1,81 \%)$, mas significativa $(\mathrm{P}<0,05)$ variação no teor de FDNcp; as equações somativas de Weiss et al. (1992) não apresentaram sensibilidade para detectar diferenças nos níveis de NDT1x. Os valores de NDT1x estimados pela fórmula de WEISS et al. (1992) (Tabela 1) são superiores aos valores tabelados por TEDESCHI et al. (2002) para silagem de milho brasileira $(65,4 \%)$, estimada pela mesma equação.

No presente estudo, as simulações de mau manejo de "desensilagem", com tempos de até 36 horas de exposição ao ar, com pequenas quantidades de silagem (19,3kg de MV) e em condições ambientais relativamente controladas, geraram diferenças significativas $(\mathrm{P}<0,05)$ na qualidade das silagens, o que, extrapolado para as condições de campo, resultaria em efeitos mais significativos, quando o manejo de 
“desensilagem” for inadequado. RANJIT \& KUNG Jr. (2000), avaliando o efeito da exposição da silagem do milho ao ar após a "desensilagem” por até 72 horas, em condições laboratoriais e com três quilos de silagem, obtiveram perdas de até $5,3 \%$ da MS, elevação do $\mathrm{pH}$ de 3,66 para 5,02 e diminuição dos teores carboidratos solúveis em água de 3,68 para $1,35 \%$ da MS, ácido láctico de 7,72 para $1,35 \%$ da MS e ácido acético de 1,82 para $0,08 \%$ da MS. Nestas situações, a relação custo/benefício poderá ser desvantajosa, haja vista que os maiores custos de utilização de silagens de milho nos sistemas pecuários se dão sobre o cultivo das plantas e no processo de ensilagem. Portanto, perdas na qualidade nutritiva durante a "desensilagem" são inoportunas. Em adição, vale ressaltar que a silagem de milho de planta inteira, quando bem manejada, é alimento volumoso de alto valor energético, de custo compatível e ambientalmente correto, pois possibilita reduzir a proporção de concentrado na dieta e amenizar os efeitos negativos advindos da produção de metano e do nitrogênio fecal excretado.

\section{CONCLUSÃO}

Os crescentes tempos de exposição ao ar após a "desensilagem" diminuem o valor nutricional de silagens de milho através de significativos aumentos nas proporções de fibra em detergente neutro e de lignina em detergente ácido, com diminuição dos carboidratos não estruturais.

\section{REFERÊNCIAS}

BACKES, A.A. et al. Determinação das frações da proteína e carboidratos de alguns alimentos conforme metodologia do CNCPS (Cornell Net Carbohydrate and Protein System). In: REUNIÃO ANUAL DA SOCIEDADE BRASILEIRA DE ZOOTECNIA, 37. 2000, Viçosa, MG. Anais... Viçosa: SBZ, 2000. Cd-rom.

BOLSEN, K.K. Managing bunker, trench, and drive-over pile silages for optimum nutritive value: four important practices. Capturado em 5 jul. 2005. Online. Disponível na Internet http://ruminantfeeds.org

CABRAL, L.S. et al. Frações de carboidratos de alimentos volumosos e suas taxas de degradação estimadas pela técnica de produção de gases. Revista Brasileira de Zootecnia, v.29, n.6, supl 1, p.2087-2098, 2000.

CAMPOS, F.P. et al. Digestibilidade in vitro/gás de volumosos exclusivos ou combinados avaliados pelo resíduo remanescente da digestão da matéria seca e produção de gás. Revista Brasileira de Zootecnia, v.30, n.5, p.1579-1589, 2001.

CLARK, J. Forage feedout losses for various storage systems. Capturado em 23 mar. 2005. Online. Disponível na Internet http://www.uwex.edu/ces/crops/uwforage/ FeedoutLossFOF.PDF
DIAS, F.N. Avaliação de parâmetros agronômicos e nutricionais em híbridos de milho (Zea mays L.) para silagem. 2002. 96f. Dissertação (Mestrado em Agronomia) - Escola Superior de Agricultura "Luiz de Queiroz”, Universidade de São Paulo.

FERREIRA, J.J. Estágio de maturação ideal para ensilagem do milho e do sorgo. In: CRUZ, J.C. et al. (Eds). Produção e utilização de silagem de milho e sorgo. Sete Lagoas: Embrapa Milho e Sorgo, 2001. p.405-428.

FILYA, I. The effect of Lactobacillus buchneri and Lactobacillus plantarum on the fermentation, aerobic stability, and ruminal degradability of low dry matter corn and sorghum silages. Journal of Dairy Science, v.86, n.11, p.3575-3581, 2003 .

HALL, M.B. et al. A simple method for estimation of neutral detergent-soluble fibre. Journal Science Food Agricultural, v.74, p.441-449, 1997.

HALL, M.B. Neutral detergent-soluble carbohydrates, Nutritional relevance and analysis. A laboratory manual. Florida: University of Florida, 2000. 42p. (Bulletin 339).

HERNÁNDEZ, F.I.L. et al. Avaliação da composição de vários alimentos e determinação da cinética ruminal da proteína, utilizando o método de produção de gás e amônia in vitro. Revista Brasileira de Zootecnia, v.31, n.1, p.243-255, 2002.

HOFFMAN, P.C.; OCKER, S.M. Quantification of milk yield losses associated with feeding aerobically unstable high moisture corn. Journal of Dairy Science, v.80, Suppl.1 p.234 (Abstr.), 1997.

MCGECHAN, M.B. A review of losses arising during conservation of grass forage: Part 2, storage losses. Journal of Agricultural and Engineering Research, v.45, p.1-30, 1990 .

MELLO, R.; NÖRNBERG, J.L. Fracionamento dos carboidratos e proteínas de silagens de milho, sorgo e girassol. Ciência Rural, v.34, n.5, p.1537-1542, 2004.

MERTENS, D.R. Challenges in measuring insoluble dietary fiber. Journal of Animal Science, v.81, p.3233-3249, 2003.

MERTENS, D.R. Gravimetric determination of amylase-treated neutral detergent fiber in feeds with refluxing in beakers or crucibles: collaborative study. Journal of AOAC International, v.85, n.6, p.1217-1240, 2002.

MORENO, J.A. Clima do Rio Grande do Sul. Porto Alegre: Secretaria da Agricultura, 1961. 41p.

MUCK, R.E.; BOLSEN, K.K. Silage preservation and silage additive products. In: BOLSEN, K.K. et al. Hay and silage management in North America. NFIA, 1991. p.105-126.

MÜHLBACH, P.R.F. Produção de leite com vacas de alta produtividade. In: REUNIÃO ANUAL DA SOCIEDADE BRASILEIRA DE ZOOTECNIA, 40., 2003, Santa Maria, RS. Anais... Santa Maria, SBZ, 2003. Cd-rom.

MULLIGAN, F.J. et al. Intake, digestibility, milk production and kinetics of digestion and passage for diets based on maize or 
grass silage fed to late lactation dairy cows. Livestock Production Science, v.74, p.113-124, 2002.

NATIONAL RESEARCH COUNCIL (NRC). Nutrient requirements of dairy cattle. 7.ed. Washington D.C.: National Academy, 2001. 360p. 2001.

NOGUERA, J.R.R. Estudo químico in situ, in vitro e microscópico da parede celular de cinco genótipos de sorgo colhidos em três épocas de corte. 2002. 177f. Tese (Doutorado em Ciência Animal) - Universidade Federal de Minas Gerais, Belo Horizonte.

OLIVEIRA, J.S. Manejo do silo e utilização da silagem de milho e sorgo. In: CRUZ, J.C. et al. (Eds). Produção e utilização de silagem de milho e sorgo. Sete Lagoas: Embrapa Milho e Sorgo, 2001. p.473-518.

QIU, X. et al. Effects of corn silage hybrid and dietary concentration of forage NDF on digestibility and performance by dairy cows. Journal of Dairy Science, v.86, n11, p.36673674, 2003.

RANJIT, N.K.; KUNG Jr., L. The effect of Lactobacillus buchneri, Lactobacillus plantarum, or a chemical preservative on the fermentation and aerobic stability of corn silage. Journal of Dairy Science, v.83, n.3, p.526-535, 2000.

RODRIGUES, P.H.M. et al. Avaliação do uso de inoculantes microbianos sobre a qualidade fermentativa e nutricional da silagem de milho. Revista Brasileira de Zootecnia, v.33, n.3, p.538-545, 2004.

ROTZ, C.A.; MUCK, R.E. Changes in forage quality during harvest and storage. In: FAHEY, G.C. et al. (Eds). Forage quality, evaluation, and utilization. Madison: University of Nebraska, 1994. p.828-868.

SENGER, C.C.D. et al. Influência da umidade e compactação sobre os carboidratos estruturais e glicídios solúveis de silagens de milho. In: REUNIÃO ANUAL DA SOCIEDADE BRASILEIRA DE ZOOTECNIA, 41., 2004, Campo Grande, MS. Anais... Campo Grande: SBZ, 2004a. Cd-room.

SENGER, C.C.D. et al. Efeito da umidade e compactação sobre o pH e as frações protéicas de silagens de milho. In: REUNIÃO ANUAL DA SOCIEDADE BRASILEIRA DE ZOOTECNIA,
41., 2004, Campo Grande, MS. Anais... Campo Grande: SBZ, 2004a. Cd-room.

SILVA, D.J.; QUEIROZ, A.C. de,. Análise de alimentos métodos químicos e biológicos. Viçosa, MG: UFV, 2002. $235 \mathrm{p}$.

SNIFFEN, C.J. et al. A net carbohydrate and protein system for evaluating cattle diets: II. Carbohydrate and protein availability. Journal Animal Science, 70, p.3562-3577, 1992

SPSS. Base 10.0 Applications Guide Copyright 1999 by SPSS. Printed in the United States of America

STRECH, E.V. Solos do Rio Grande do Sul. Porto Alegre: EMATER-RS; UFRGS, 2002. 107p.

TEDESCHI, L.O. et al. Development and evaluation of tropical feed library for the Cornell net carbohydrate and protein system model. Scientia Agricola, v.59, n.1, p.1-18, 2002.

VALADARES F $\underline{\mathbf{o}}$, S. de C. et al. Tabelas brasileiras de composição de alimentos para bovinos CQBAL 2.0 Viçosa, MG: UFV, 2002. 297p.

VAN SOEST, P.J. Nutritional ecology of the ruminant. Ithaca: Cornell University, 1994. 476p.

WALTER, M. Amido resistente: metodologias de quantificação e resposta biológica em ratos. 2005. $96 \mathrm{f}$ Dissertação (Mestrado em Ciência e Tecnologia de Alimentos) - Universidade Federal de Santa Maria, Santa Maria, RS.

WEATHERBURN, M.W. Phenol-hypochlorite reaction for determination of ammonia. Analytical Chemistry, v.39, p.971-974, 1967.

WEISS, W.P. Adjusting net energy values of feeds fed to dairy cows. Capturado em 13 abr. 2005 Online. Disponível na Internet http://ruminantfeeds.org

WEISS, W.P. et al. A theoretically-based model for predicting total digestible nutrient values of forages and concentrates. Animal Feed Science and Technology, 39, p.95-110, 1992.

WOOLFORD, M.K. The silage fermentation. New York: Marcel Dekker, 1990. 350p. 